Article

\title{
Constructing Supramolecular Frameworks Based Imidazolate-Edge-Bridged Metallacalix[3]arenes via Hierarchical Self-Assemblies
}

\author{
Bo Cui, Lirong Zhao, Jin Tong *, Xiayan Wang and Shuyan Yu
}

check for updates

Citation: Cui, B.; Zhao, L.; Tong, J.;

Wang, X.; Yu, S. Constructing

Supramolecular Frameworks Based

Imidazolate-Edge-Bridged

Metallacalix[3]arenes via Hierarchical

Self-Assemblies. Crystals 2022, 12,

212. https://doi.org/10.3390/

cryst12020212

Academic Editor: Ana M.

Garcia-Deibe

Received: 30 December 2021

Accepted: 29 January 2022

Published: 31 January 2022

Publisher's Note: MDPI stays neutral with regard to jurisdictional claims in published maps and institutional affiliations.

Copyright: (C) 2022 by the authors. Licensee MDPI, Basel, Switzerland. This article is an open access article distributed under the terms and conditions of the Creative Commons Attribution (CC BY) license (https:// creativecommons.org/licenses/by/ $4.0 /)$.
Beijing Key Laboratory for Green Catalysis and Separation, Center of Excellence for Environmental Safety and Biological Effects, Department of Environment and Life, Beijing University of Technology, Beijing 100124, China; cb@163.com (B.C.); zlr@163.com (L.Z.); xyw@bjut.edu.cn (X.W.); ysy@bjut.edu.cn (S.Y.)

* Correspondence: jintong@bjut.edu.cn

\begin{abstract}
Hierarchical self-assembly of novel supramolecular structures has obtained increasing attention. Herein we design and synthesize the palladium(II)-based molecular basket-like structures, as structural analog of metallacalix[3]arene $\left[\mathbf{M}_{3} \mathbf{L}_{3}\right]^{3+}\left(\mathrm{M}=(\mathrm{dmbpy}) \mathrm{Pd}\right.$, (phen)Pd; $\mathrm{dmbpy}=4,4^{\prime}$ -dimethyl-bipyridine; phen =1,10-phenanthroline), by coordination-driven self-assembly from imidazolate-containing ligand [4,5-bis(2,5-dimethylthiophen-3-yl)-1H-imidazole (HL) with palladium(II) nitrate precursors (dmbpy) $\mathrm{Pd}\left(\mathrm{NO}_{3}\right)_{2}$ and (phen) $\mathrm{Pd}\left(\mathrm{NO}_{3}\right)_{2}$. The difference of the palladium(II) nitrate precursors with $\pi$-surface in complex produces variations of the two-dimensional (2-D) and three-dimensional (3-D) high-ordered supramolecular architectures, constructed by $\pi \cdots \pi$ packing and hydrogen bonding interactions, with metallacalixarenes as building blocks. These results provide perceptions of further exploring the hierarchical assembly of supramolecular structures based on $\pi \cdots \pi$ packing and multiple hydrogen bonding.
\end{abstract}

Keywords: self-assembly; bridging ligand; hydrogen bonding interaction; $\pi \cdots \pi$ Stacking; Single crystal X-ray

\section{Introduction}

Supramolecular self-assembly is ubiquitous in nature, and builds up the high-ordered structures through spontaneous organization of building blocks driven by noncovalent interactions [1-4]. Recently, it has become more clearer that the nature often constructs complex structures by employing hierarchical self-assembly strategies that bring the compounds together step-by-step via multiple noncovalent interactions [5-8]. Inspired by the dedicated biological structures in nature, hierarchical self-assembly strategies have been increasingly used to create well-defined assemblies with high complexity [9-11].

Designing and constructing molecular architectures via metal-driven self-assembly has developed rapidly in the last few years [12,13]. These techniques come down to the design of multidentate ligands and choice of metal ions to afford self-assembled molecules under suitable reaction conditions [14-16]. Apart from the synthesis of new self-assemblers, the understanding and employing of non-covalent interactions, including hydrogen bond interactions and $\pi-\pi$ packing, is fundamentally important to develop the field of crystal growing and designing [17-25]. These intermolecular interactions make great contributions to the supramolecular association [26-30].

The synthesis and structural studies of a variety of palladium(II) molecular structures as structural analogs of metallacalixarenes are well studied by changing different cisprotecting palladium(II) components or counter-anions or ligands in our previous work and others [31-47]. However, the hierarchical self-assembly of palladium(II)-based selfassembly molecules has been rarely studied [48,49]. Herein, we design nitrogen donor compounds with thiophene groups as ligands, and choose palladium(II) components 
with $\pi$-surface in the cis-protecting parts (Scheme 1) and nitrate/hexafluorophosphate as counter-anions, respectively. We study the difference of the palladium(II) components in the construction of configuration and the self-assembly step-by-step.

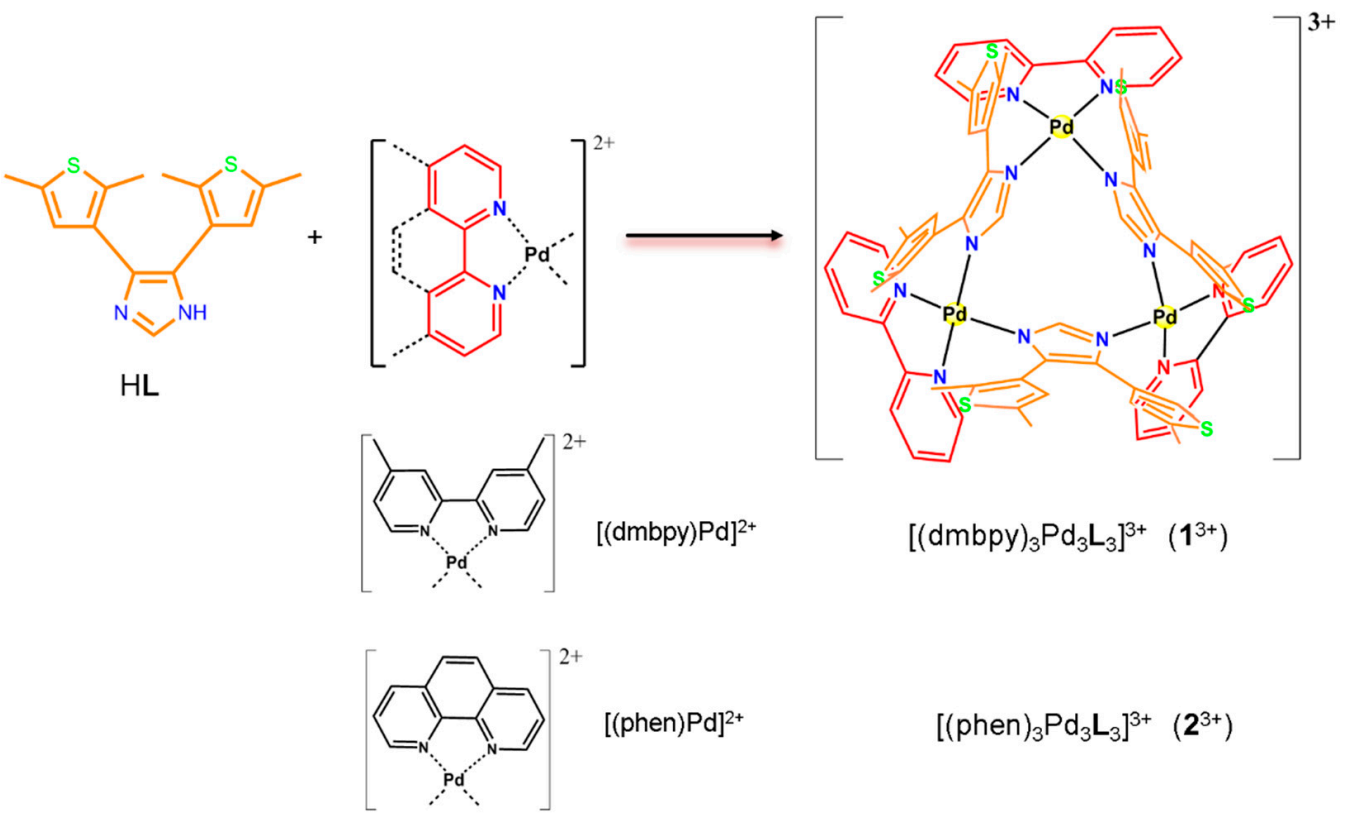

Scheme 1. Scheme of the synthesis of molecular basket-like metallacalixarenes via bidentate imidazole-based ligands.

As an extension of our previous studies of metallacalixarene analogs via self-assembly approach, herein we present the design and synthesis of $\left[\mathbf{M}_{3} \mathbf{L}_{3}\right]^{3+}$-type metallacalixarenes derived from imidazole-bridged bidentate ligand $\mathrm{HL}$ by reacting with coordinated palladium(II) precursors (phen) $\mathrm{Pd}\left(\mathrm{NO}_{3}\right)$ and (dmbpy) $\mathrm{Pd}\left(\mathrm{NO}_{3}\right)_{2}$ in aqueous media via selfassembly (Scheme 1). Single crystal X-ray diffraction and elemental analysis techniques were used to characterize the solid structures of two new complexes.

\section{Experimental Section}

\subsection{Materials and Instrumentation}

Chemicals purchased were of analytical grade and used without purification. The ${ }^{1} \mathrm{H}$ NMR spectra were recorded on a BRUKER AVANCE III HD $400 \mathrm{M} \mathrm{Hz}$ spectrometer (Bruker Corporation, Berlin, Germany). Elemental analyses (EA) for C, $\mathrm{H}$ and $\mathrm{N}$ were performed on a EA 1108 (Carlo Erba Instruments) elemental analyzer. Ligand HL was synthesized according to a reported literature $[50,51]$.

\subsubsection{Synthesis of Complex $\left[(\mathrm{dmbpy})_{3} \mathrm{Pd}_{3} \mathrm{~L}_{3}\right]\left(\mathrm{NO}_{3}\right)_{3}\left(\mathbf{1}^{\circ} \mathrm{NO}_{3}\right)$}

Combination of (dmbpy) $\mathrm{Pd}\left(\mathrm{NO}_{3}\right)_{2}(14.10 \mathrm{mg}, 0.034 \mathrm{mmol})$ with a suspension of $\mathrm{HL}$ (9.81 $\mathrm{mg}, 0.034 \mathrm{mmol})$ in $\mathrm{H}_{2} \mathrm{O}(1 \mathrm{ml})$ and acetonitrile $(1 \mathrm{ml})$, the mixture was stirred for $24 \mathrm{~h}$ at $25{ }^{\circ} \mathrm{C}$. The desired product $1 \bullet 3 \mathrm{NO}_{3}$ was obtained as a light-yellow precipitate (yield: $65 \%$ ).

The $\mathrm{PF}_{6}$-salt $\left[(\mathbf{d m b p y})_{3} \mathbf{P d}_{3} \mathbf{L}_{3}\right]\left(\mathbf{P F}_{6}\right)_{3}\left(\mathbf{1}^{-3} \mathbf{P F}_{6}\right)$ was obtained with addition of excess of $\mathrm{KPF}_{6}$ to solution, resulting in the deposition of $\mathbf{1 \bullet}^{-3 \mathbf{P F}_{6}}$ as yellow solids. The solids were filtered, washed with water and then dried (yield: $85 \%$ ). Anal. Calc. for $\mathrm{C}_{81} \mathrm{H}_{81} \mathrm{~F}_{18} \mathrm{~N}_{12} \mathrm{P}_{3} \mathrm{Pd}_{3} \mathrm{~S}_{6}$ : C 44.85, H 3.76, N 7.75; found: C 44.92, H 3.69, N 7.71.

\subsubsection{Synthesis of Complex $\left[(\text { phen })_{3} \mathrm{Pd}_{3} \mathrm{~L}_{3}\right]\left(\mathrm{NO}_{3}\right)_{3}\left(2 \bullet 3 \mathrm{NO}_{3}\right)$}

A combination of (phen) $\mathrm{Pd}\left(\mathrm{NO}_{3}\right)_{2}(13.96 \mathrm{mg}, 0.034 \mathrm{mmol})$ with a suspension of $\mathrm{HL}$ (9.81 mg, $0.034 \mathrm{mmol})$ in $\mathrm{H}_{2} \mathrm{O}(1 \mathrm{ml})$ and acetonitrile $(1 \mathrm{ml})$ was stirred for $24 \mathrm{~h}$ at $25^{\circ} \mathrm{C}$ 
The designed product $\mathbf{2} \bullet \mathbf{3} \mathrm{NO}_{3} \cdot$ was obtained as yellow micro-crystals (yield: $55 \%$ ). Anal. Calc. for $\mathrm{C}_{81} \mathrm{H}_{69} \mathrm{~N}_{15} \mathrm{O}_{9} \mathrm{Pd}_{3} \mathrm{~S}_{6}$ : C 50.99, H 3.64, N 11.01; found: C 50.22, H 3.69, N 11.21.

\subsection{X-ray Structure Determination and Structure Refinement}

Single crystal X-ray diffraction data for compound HL and complexes $\mathbf{1 \bullet} 3 \mathbf{P F}_{\mathbf{6}}$ and $\mathbf{2} \bullet \mathbf{3} \mathrm{NO}_{3}$ are collected on a Rigaku Super Nova CCD X-ray diffractometer equipped with low temperature device and a fine-focus sealed-tube $X$-ray source (graphite monochromated $\mathrm{Cu}-\mathrm{K} \alpha$ radiation, $\lambda=1.54184 \AA$; Mo-K $\alpha$ radiation, $\lambda=0.71073 \AA$; Ga-K $\alpha$ radiation, $\lambda=1.34139 \AA$ ). Suitable single crystals were picked from the mother liquid, attached to a glass loop and transferred to a designed cold stream of liquid nitrogen (173 K) for data collections. Raw data collection and reduction were done using APEX2 software. The SHELXTL direct methods was used to solve all the crystal structures, which was again refined by employing full-matrix least-squares on $\mathrm{F}^{2}$ by using the SHELXTL software program and expanded using Fourier techniques [52,53]. All non-H atoms of the complexes were refined with anisotropic thermal parameters. The hydrogen atoms were included in idealized positions. Final residuals, along with the unit cell, space group, date collection and refinement parameters, are presented in Table 1. Tables S1 and S2 give crystallographic details and selected bond distances and angles. Crystallographic data for structures reported in this paper have been deposited in the Cambridge Crystallographic Data Center under reference numbers CCDC 2126504, 2116570-2116571. These data can be downloaded via www.ccdc.cam.ac.uk/deposit@ccdc.cam.ac.uk (28 December 2021).

Table 1. Crystal data and structure refinement for $\mathrm{HL}, 1 \bullet 3 \mathrm{PF}_{6}$ and $2 \bullet 3 \mathrm{NO}_{3}$.

\begin{tabular}{|c|c|c|c|}
\hline & HL & $1 \bullet 3 \mathrm{PF}_{6}$ & $2 \bullet 3 \mathrm{NO}_{3}$ \\
\hline Formula & $\mathrm{C}_{32} \mathrm{H}_{32} \mathrm{~N}_{4} \mathrm{~S}_{4}$ & $\mathrm{C}_{81} \mathrm{H}_{81} \mathrm{~F}_{18} \mathrm{~N}_{12} \mathrm{~S}_{6} \mathrm{P}_{3} \mathrm{Pd}_{3}$ & $\mathrm{C}_{81} \mathrm{H}_{69} \mathrm{~N}_{15} \mathrm{O}_{9} \mathrm{~S}_{6} \mathrm{Pd}_{3}$ \\
\hline Formula weight & 600.85 & 2169.04 & 1908.07 \\
\hline crystal system & triclinic & triclinic & monoclinic \\
\hline space group & $P-1$ & P-1 & $\mathrm{C} 2 / \mathrm{c}$ \\
\hline$a[\AA]$ & $9.6510(7)$ & $16.8822(9)$ & $33.3674(14)$ \\
\hline$b[\AA]$ & $12.1557(10)$ & $18.9348(7)$ & $20.8260(9)$ \\
\hline$c[\AA]$ & $13.4203(11)$ & $18.9951(7)$ & $35.088(3)$ \\
\hline$\alpha\left[^{\circ}\right]$ & 98.101(3) & $60.273(3)$ & 90 \\
\hline$\beta\left[{ }^{\circ}\right]$ & 91.796(3) & $74.678(3)$ & $115.090(5)$ \\
\hline$\gamma\left[{ }^{\circ}\right]$ & $101.972(2)$ & $89.701(4)$ & 90 \\
\hline $\mathrm{V}\left[\AA^{3}\right]$ & $1521.8(2)$ & $5027.8(4)$ & $22082(2)$ \\
\hline $\mathrm{Z}$ & 2 & 2 & 8 \\
\hline$\rho_{\text {calcd }},\left[\mathrm{g} / \mathrm{cm}^{-3}\right]$ & 1.311 & 1.433 & 1.148 \\
\hline$\mu\left[\mathrm{mm}^{-1}\right]$ & 0.341 & 6.581 & 0.646 \\
\hline$F(000)$ & 632 & 2184 & 7728 \\
\hline $2 \theta \max \left[{ }^{\circ}\right]$ & 56.764 & 69.999 & 27.000 \\
\hline no. unique data & 7567 & 18,840 & 24,101 \\
\hline Parameters & 5616 & 1126 & 1135 \\
\hline $\mathrm{GOF}\left[\mathrm{F}^{2}\right]$ & 1.049 & 1.050 & 1.056 \\
\hline $\mathrm{R}\left[\mathrm{F}^{2}>2 \sigma\left(\mathrm{F}^{2}\right)\right]$ & 0.0568 & 0.0404 & 0.0508 \\
\hline $\mathrm{wR}\left[\mathrm{F}^{2}\right]$ & 0.1755 & 0.0977 & 0.1035 \\
\hline
\end{tabular}

\section{Results and Discussion}

\subsection{Ligand Synthesis and Structural Characterization}

Compound 4,5-bis(2,5-dimethylthiophen-3-yl)-1H-imidazole (HL) as a ligand was prepared according to the literature, and charactered with spectroscopic data (Figure S1 in the Supplementary Materials) [50]. Single crystals of ligand HL were obtained by evaporating chloroform solution, and the X-ray crystallographic data further confirms the structure (Figure 1). The asymmetric unit of HL contains two independent molecules, and neighboring molecules are connected through $[\mathrm{N}-\mathrm{H} \cdots \mathrm{N}]$ hydrogen bonds $[\mathrm{r}(\mathrm{N} \cdots \mathrm{N})=2.819 \AA$ and $2.844 \AA ; \angle \mathrm{N}-\mathrm{H} \cdots \mathrm{N}=174.48^{\circ}$ and $\left.170.74^{\circ}\right]$ to give a supramolecular chain. It is worth men- 
tioning that the 1-D chain is also stabilized by another kind of weak interaction as [C-H $\cdots \mathrm{S}$ ] hydrogen bonds with C...S distances of $3.725 \AA$ and $3.743 \AA$ [54], which are shorter than the C‥S distances reported in the literature [51], which is of important weak interaction in the hierarchical self-assembly for the construction of supramolecular frameworks, with imidazolate-edge-bridged metallacalixarenes as building blocks.

(a)

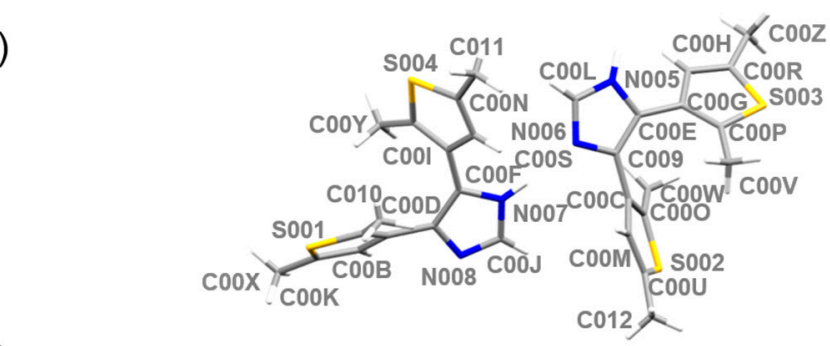

(b)

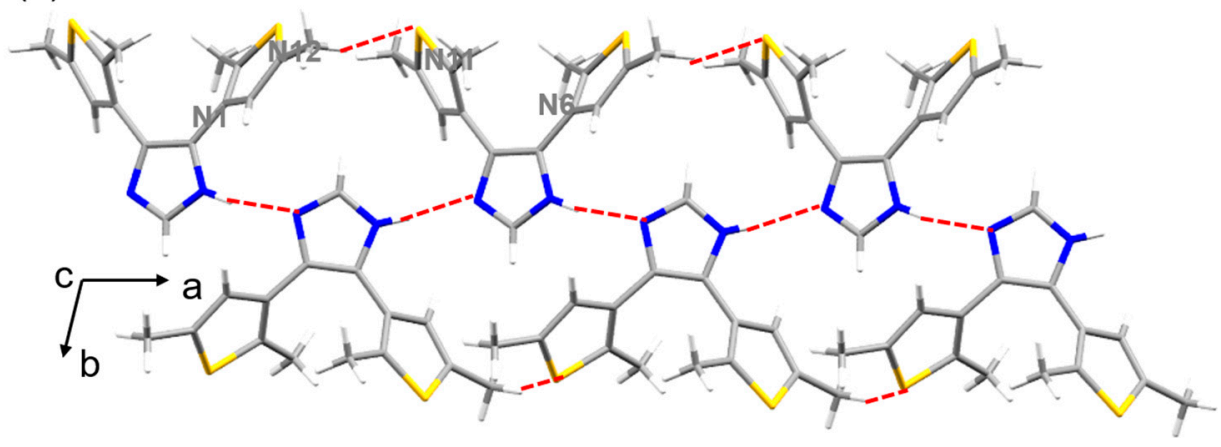

Figure 1. Crystal structure of (a) $\mathrm{HL}$ and (b) supramolecular chain structure in $\mathrm{HL}$ via[C-H $\cdots \mathrm{S}]$ and $[\mathrm{N}-\mathrm{H} \cdots \mathrm{N}]$ hydrogen bonds.

\subsection{Synthesis and Structural Characterization of Metallacalix[3]arenes}

Complexes $\left[(\mathrm{dmbpy})_{3} \mathrm{Pd}_{3} \mathrm{~L}_{3}\right]\left(\mathrm{NO}_{3}\right)_{3}\left(1 \bullet 3 \mathrm{NO}_{3}\right)$ and $\left[(\mathrm{phen})_{3} \mathrm{Pd}_{3} \mathrm{~L}_{3}\right]\left(\mathrm{NO}_{3}\right)_{3}\left(2 \bullet 3 \mathrm{NO}_{3}\right)$ were synthesized by metal-directed self-assembly. Reacting $\mathrm{HL}$ with one equivalent of cis-protected palladium(II) nitrate precursor (dmbpy)Pd- $\mathbf{N O}_{3}$ and (phen) ${ }_{3} \mathbf{P d}-\mathbf{N O}_{3}$ in $\mathrm{H}_{2} \mathrm{O} /$ acetonitrile $(1: 1, v / v)$ at room temperature gave a yellow reaction mixture (see Exp. Sect.). The conditions were fine-tuned to obtain appropriate crystals for single crystals $\mathrm{XRD}$ of $2 \cdot 3 \mathrm{NO}_{3}$ and $\mathbf{1} \bullet 3 \mathrm{PF}_{6}$, which was obtained by adding aqueous ammonium hexafluorophosphate to the solution of $1 \bullet 3 \mathrm{NO}_{3}$. In these structures, every ligand (HL) deprotonates spontaneously, and acts as a monovalent $\left[(\mathbf{L})^{-}\right]$building unit. Complexes $1 \bullet 3 \mathrm{NO}_{3}$ and $2 \bullet 3 \mathrm{NO}_{3}$ were characterized by ${ }^{1} \mathrm{H}$ NMR spectrometry. The ${ }^{1} \mathrm{H}$ NMR spectra of both new complexes have been worked out in DMSO- $d_{6}$ (Figure S8). Unfortunately, the signals of all protons of the cis-protecting units and ligands are observed as broad signals, which could not be assigned exactly. Molecular structure of complexes $\mathbf{1} \bullet \mathbf{3} \mathbf{P F}_{6}$ and $\mathbf{2} \bullet \mathbf{3} \mathbf{N O}_{3}$ are further confirmed by satisfactory $\mathrm{X}$-ray diffraction and elemental analysis.

Single crystals of $1 \bullet 3 \mathbf{P F}_{6}$ were collected by the vapor diffusion of diethylether into the acetonitrile solution, and single crystals of $2 \bullet 3 \mathbf{N O}_{3}$ were obtained from aqueous solutions. Part of the bond lengths and bond angles are listed in Tables S1 and S2. Complex $\mathbf{1}^{\mathbf{3}} \mathbf{P F}_{\mathbf{6}}$ crystallizes in triclinic crystal system and P-1 space group, but complex $2 \bullet 3 \mathrm{NO}_{3}$ crystallizes in monoclinic crystal system and $\mathrm{C} 2 /$ c space group. Both contain three cationic $\left\{\mathrm{Pd}\left(\mathrm{N}^{\wedge} \mathrm{N}\right)\right\}$ units bound to three anionic ligands with three hexafluorophosphate or nitrate as counteranions and the crystal structures of the complexed cation are displayed in Figure 2. One of the hexafluorophosphates or nitrates is present at the bottom of the basket-shaped structures, as shown in Figures S2 and S3. 

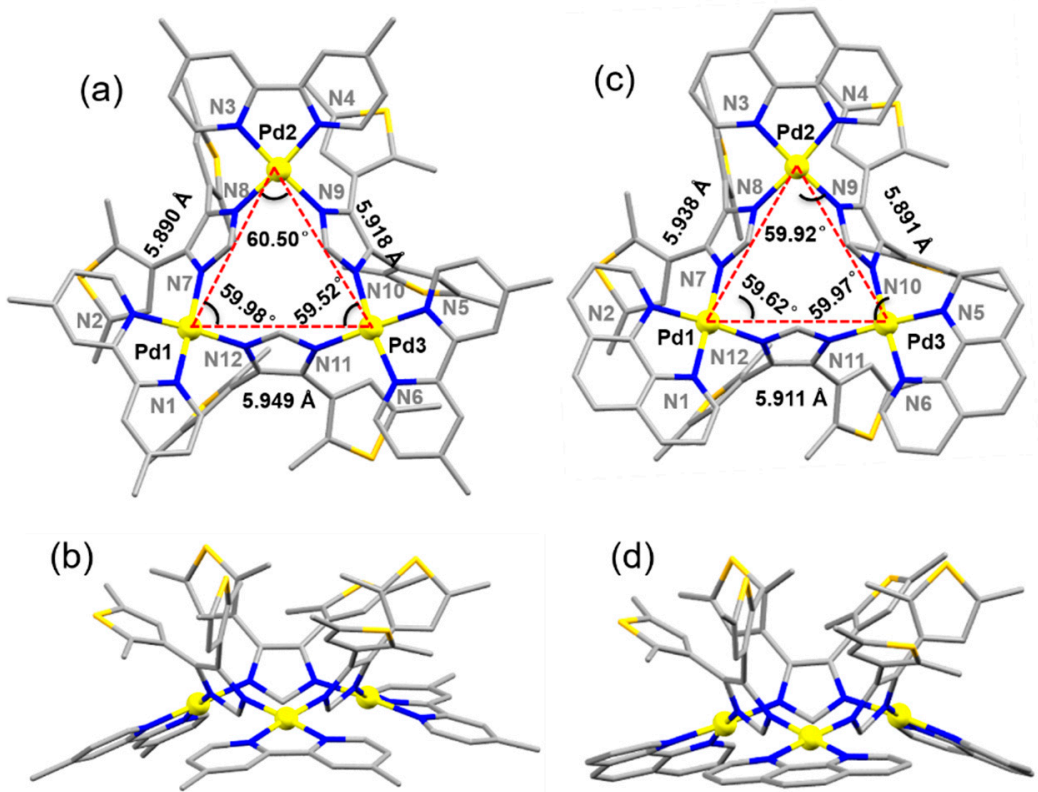

Figure 2. Crystal structures of complexed cations $\mathbf{1}^{3+}$ and $2^{3+}$ via metal-ligand coordination: top views $(\mathbf{a}, \mathbf{c})$ and side views (b,d) (hydrogens, anions, and solvent molecules are excluded for clarity).

Taking complex $\mathbf{1} \cdot 3 \mathrm{PF}_{6}$ as an example, the three dimethylthiophen-imidazolate ligands form the basket wall; all ligands are linked by [(dmbpy)Pd] units in a syn, syn, syn orientation. All palladium(II) atoms make up a triangle with Pd ...Pd distances of $5.949 \AA$, $5.918 \AA$ and $5.890 \AA$, as shown in Figure 2. The dimensions of the molecular basket are $5.974 \AA, 5.985 \AA, 6.202 \AA, 5967 \AA, 6.189 \AA$ and $5.920 \AA$ for the upper-rim lengths (e.g., the distances between two $S$ atoms of thiophene groups); $2.374 \AA$, $2.228 \AA$ and $2.133 \AA$ for the lower-rim lengths between the protons of imidazolium units, and $6.63 \AA$ in depth (Figure S4). The thiophene groups attached to the imidazole appear haphazard, due to the freely rotating nature of the single bond. In complex $1 \bullet 3 \mathrm{PF}_{6}$, the thiophene sulphur atoms of one ligand are $\mathrm{H}$-bonded to methyl groups $(\mathrm{S} \cdots \mathrm{H}-\mathrm{C})$ from the ligand to form a dimer. 2-D growth is found resulting from $\pi \cdots \pi$ stacking and multiple [S $\cdots \mathrm{H}-\mathrm{C}]$ hydrogen bonding interactions in complex $\mathbf{1}^{\mathbf{3}} \mathbf{P F}_{\mathbf{6}}$ (Figure 3 ).

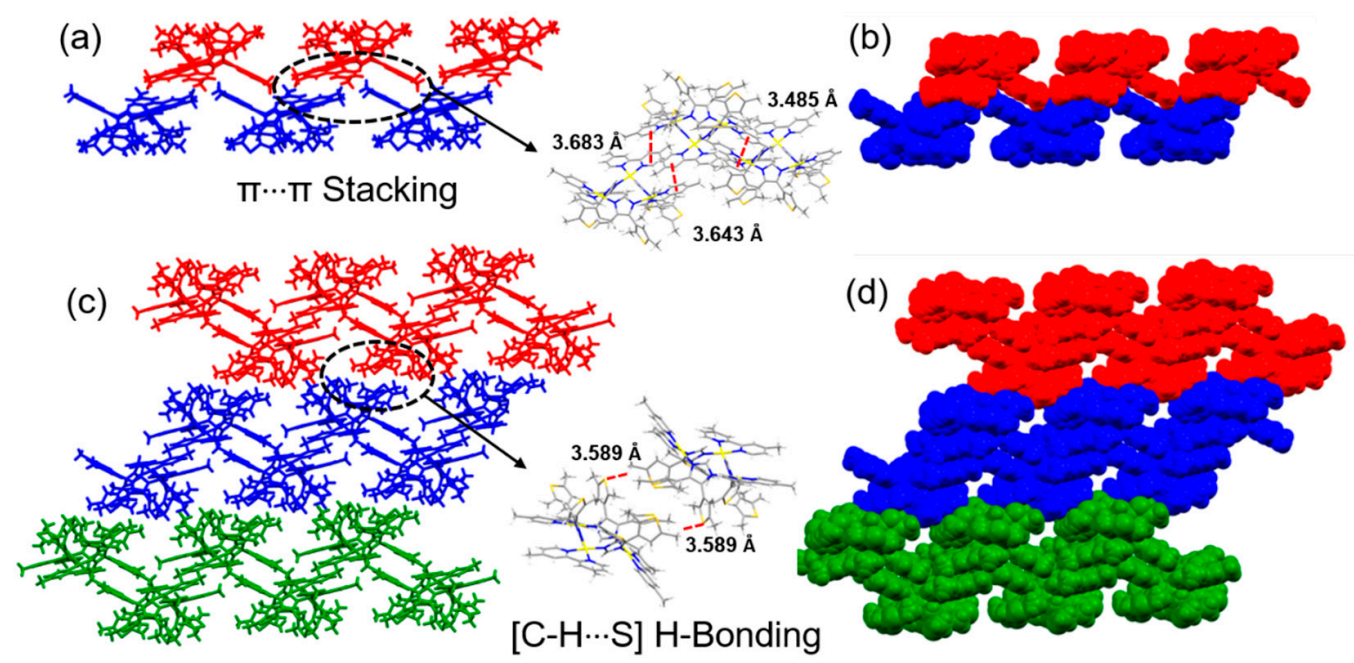

Figure 3. Supramolecular 1-D structural fragments in $\mathbf{1} \bullet \mathbf{3} \mathbf{P F}_{6}$ via $\pi \cdots \pi$ packing $(\mathbf{a}, \mathbf{b})$ and Supramolecular 2-D structure of $\mathbf{1 \bullet 3} \mathbf{P F}_{\mathbf{6}}$ via $\pi \cdots \pi$ packing and [C-H $\cdots \mathrm{S}$ ] hydrogen bonds $(\mathbf{c}, \mathbf{d})$ (the C-S distance of $3.589 \AA$ and the $\mathrm{CH}-\mathrm{S}$ angle of $132.81^{\circ}$ ). 
The non-bonded distances of the triangle $\mathrm{Pd}_{3}$ and the dimensions of the molecular basket $2 \bullet 3 \mathbf{N O}_{3}$ are listed in Figure 2. Interestingly, the imidazolate units are oriented same in the trimers relative to the $\mathrm{Pd}_{3}$ plane. Three $\mathrm{C}$ atoms between two $\mathrm{N}$ atoms of the imidazole units are positioned to the same side and oriented in toward one another, which close off one side of the $\mathrm{Pd}_{3}$ plane, including an anion of hydrogen bonded (Figure S3). On the opposite side, the thiophene groups attached to the ethylene units, designated as the all "up" configuration, rendering a basket-like open side. In complex $\mathbf{2} \bullet \mathbf{3} \mathbf{N O}_{3}$, the thiophene sulphur atoms of the ligand are H-bonded to methyl groups $(\mathrm{S} \cdots \mathrm{H}-\mathrm{C})$ from the ligand to form a dimer. Nevertheless, 3-D growth is found resulting from $\pi \cdots \pi$ stacking and multiple $[\mathrm{S} \cdots \mathrm{H}-\mathrm{C}]$ hydrogen bonding interactions in complex $2 \bullet 3 \mathrm{NO}_{3}$ (Figure 4 ).
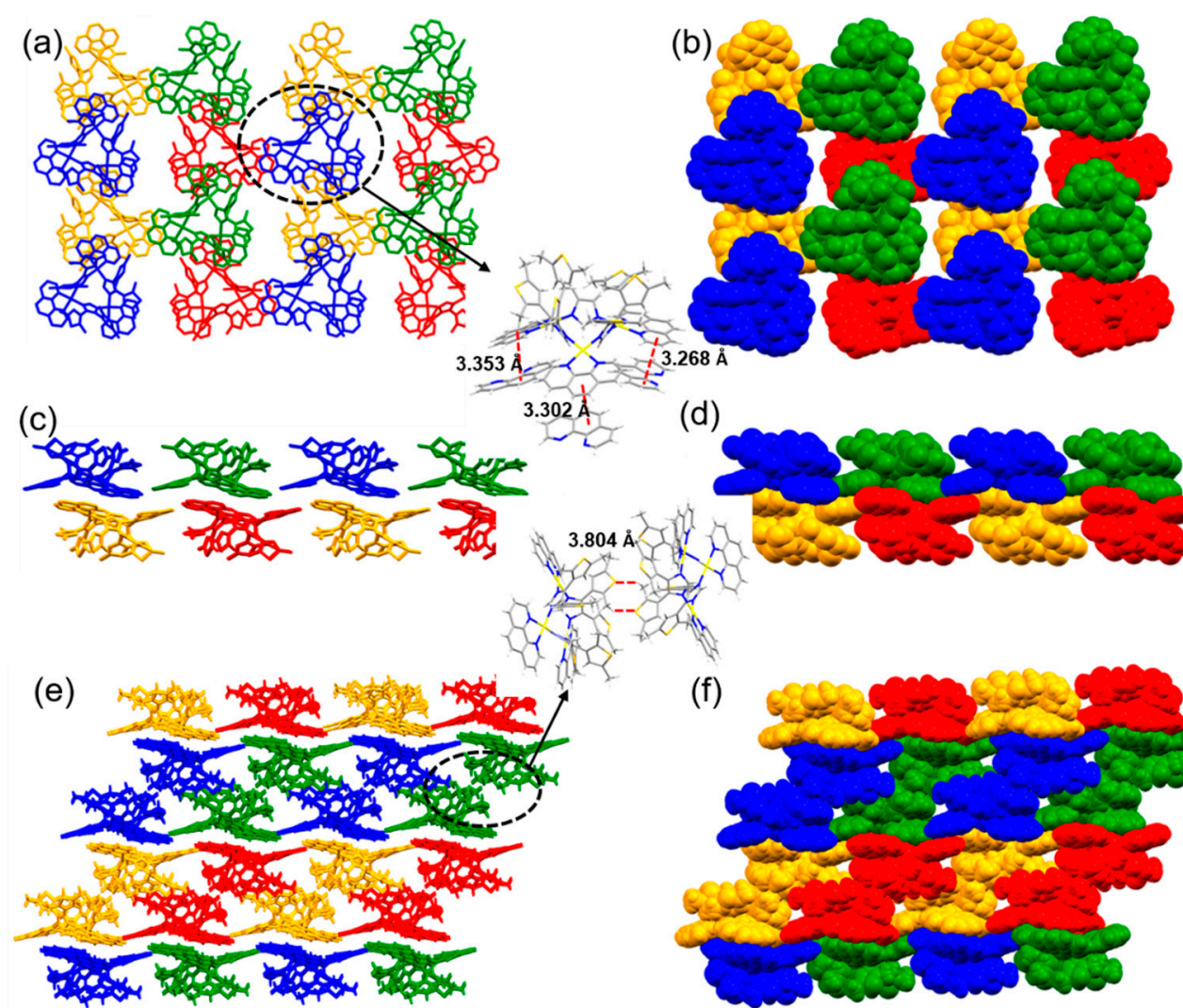

(d)
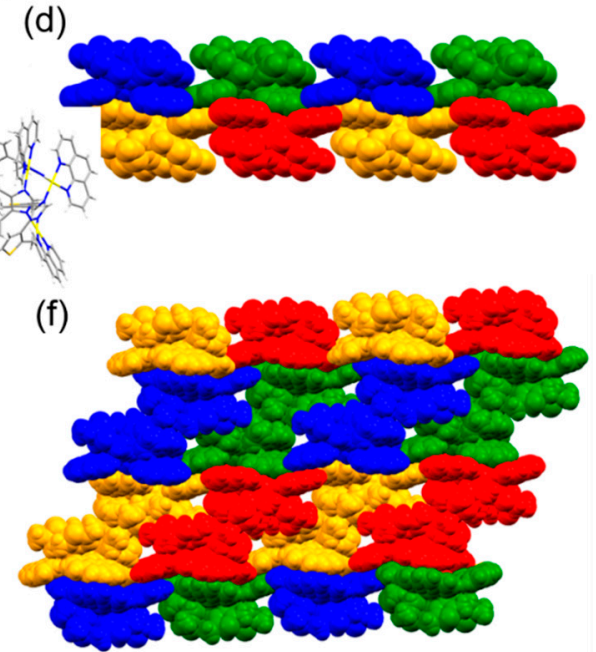

Figure 4. Supramolecular 2-D structural fragments in $2 \bullet 3 \mathrm{NO}_{3}$ via $\pi \cdots \pi$ packing (a-d) and Supramolecular 3-D structure of $\mathbf{2} \bullet \mathbf{3} \mathrm{NO}_{3}$ via $\pi \cdots \pi$ packing and [C-H $\cdots$ S] hydrogen bonds $(\mathbf{e}, \mathbf{f})($ the C-S distance of $3.804 \AA$, the C-H $\cdots$ S angle of $147.48^{\circ}$ ).

\subsection{Influence of cis-Protecting Groups on the Crystal Engineering}

The more interesting points of the crystal structure are displayed by analyzing the packing model. One Hydrogen bonded dimer is observed to be associated with two more dimers via $\pi-\pi$ packing of the planer 'dmbpy' or 'phen' moieties [55-57] in an interoverlaying manner, resulting in a 2-D layer and 3-D network, as shown in Figures 3 and 4. All the crystal structures are stabilized via the $\pi \cdots \pi$ packing between planar 'dmbpy' or 'phen' components and hydrogen bonding weak interactions involving thiophene groups (C$\mathrm{H}$ ‥S). Supramolecular frameworks with imidazolate-edge-bridged metallacalix[3]arenes are constructed by employing via coordination self-assembly, $\pi \cdots \pi$ packing and hydrogenbonded interactions step-by-step. Further interactions seen in the packing are discussed in a later section.

The presence of $\pi$-surface in the cis-protecting units and thiophene groups is quite capable of influencing the crystal packing via hierarchical self-assembly. In the case of the complex $1 \bullet 3 \mathbf{P F}_{6}$, one molecular basket is linked by two other neighboring molecules via $\pi \cdots \pi$ packing, whereupon the 'dmbpy' units of $\mathbf{1} \cdot \mathbf{3} \mathbf{P F}_{\mathbf{6}}$ are stacked in a parallel manner 
with distances of $\sim 3.640 \AA$ and $3.850 \AA$. Then, they were arranged in a 1-D $\pi$-polymer as a chain, as already shown in Figure 3. The more interesting point is to note that a set of molecular chains is stacked to other sets via double [C-H..S] hydrogen bonding interactions in crystal packing of $\mathbf{1 \bullet}^{3} \mathbf{P F}_{6}$, resulting in a 2-D panel.

In the case of complex $2 \cdot \mathbf{e} \mathrm{NO}_{3}$, molecules are stacked in the crystal engineering in a perfectly packing manner because of $\pi \cdots \pi$ packing. The $\pi \cdots \pi$ packing displays more favorable of 'phen' units due to its large aromatic ring. Thus, there is an almost faceto-face $\pi \cdots \pi$ stacking of 'phen' units in a triangle manner, where three 'phen' units of a molecular triangle overlap three other 'phen' units from three adjacent molecules to form a 2-D layer (Figure 3). Then, a set of molecular layers is linked to other sets via double $[\mathrm{C}-\mathrm{H} \cdots \mathrm{S}]$ hydrogen bonding interactions, one above and one below, resulting in a 3-D supramolecular framework (Figure 4).

\section{Conclusions}

In this contribution, we have presented metal-driven self-assembling molecular basketlike nano-cavities as structural analogs of $\left[\mathbf{M}_{3} \mathbf{L}_{3}\right]^{3+}$-type metallacalix[3]arene, using cisprotecting palladium(II) components with $\pi$-cloud and novel rigid imidazolate-bridging ligands that differ from previous ligands of this type by having thiophene as functionalized groups. The structures of these two metallacalixarenes have been confirmed by element analysis and single crystal X-ray diffraction methods. The crystallography shows that one anion $\left(\mathrm{NO}_{3}{ }^{-}\right.$or $\left.\mathrm{PF}_{6}{ }^{-}\right)$binds at the lower rim of the basket via $\mathrm{C}-\mathrm{H} \cdots$ anion weak interaction within basket-shaped metallacalixarenes. In particular, the design of ligands and choice of the $\pi$-cloud in the cis-protecting palladium(II) units could control the crystal growth, and guided us to study the hierarchical self-assembly in the crystalline state through $\pi \cdots \pi$ packing and hydrogen bonding weak interaction. Further investigation will focus on their potentials as chemsensors for the multiple recognition of ions. These results bring new approaches for achieving 2-D and 3-D high-ordered supramolecular structure-based hierarchical self-assemblies and targeted functionalities.

Supplementary Materials: The following supporting information can be downloaded at: https:// www.mdpi.com/article/10.3390/cryst12020212/s1, Figure S1: 1H NMR spectrum of HL. Tables S1 and S2: crystallographic data of complexes 1.3PF6 and $\mathbf{2} \cdot \mathbf{3} \mathrm{NO}_{3}$. Figures S2 and S3: Top view and side view of the basket-shape structures with one anion of $1 \cdot 3 \mathrm{PF} 6$ and $2 \cdot 3 \mathrm{NO}_{3}$. Figures S4 and S5: Top view and side view of the basket-shape structures with size of 1.3PF6 and $\mathbf{2} \cdot \mathbf{3} \mathrm{NO}_{3}$. Figures $\mathrm{S} 6$ and S7: the packing model of the structures of $\mathbf{1} \cdot \mathbf{3} \mathbf{P F}_{\mathbf{6}}$ and $\mathbf{2} \cdot \mathbf{3} \mathbf{N O}_{3}$.

Author Contributions: Conceptualization, J.T.; methodology and investigation, B.C.; formal analysis, L.Z.; writing—original draft preparation, review and editing, J.T.; supervision, X.W.; and supervision, S.Y. All authors have read and agreed to the published version of the manuscript.

Funding: We thank the National Natural Science Foundation of China (21906002), Beijing Natural Science Foundation of China (2212002), Beijing Municipal Science and Technology Project (KM202010005010) and Beijing Outstanding Young Scientist Program (BJJWZYJH01201910005017) for support with funding.

Data Availability Statement: Not applicable.

Conflicts of Interest: All authors declare no conflict of interest.

\section{References}

1. Atwood, J.L.; Davies, J.E.D.; MacNicol, D.D.; Voegtle, F.; Suslick, K.S. Comprehensive Supramolecular Chemistry; Elsevier: Oxford, UK, 1996.

2. Grimes, J.M.; Burroughs, J.N.; Gouet, P.; Diprose, J.M.; Malby, R.; Ziéntara, S.; Mertens, P.P.C.; Stuart, D.I. The atomic structure of the blue tongueviruscore. Nature 1998, 395, 470-478. [CrossRef] [PubMed]

3. Whitesides, G.M.; Grzybowski, B. Self-assembly at all scales. Science 2002, 295, 2418-2421. [CrossRef] [PubMed]

4. Amabilino, D.B.; Smith, D.K.; Steed, J.W. Supramolecular materials. Chem. Soc. Rev. 2017, 46, 2404-2420. [CrossRef] [PubMed]

5. Chen, L.J.; Yang, H.B. Construction of Stimuli-Responsive Functional Materials via Hierarchical Self-Assembly Involving Coordination Interactions. Acc. Chem. Res. 2018, 51, 2699-2710. [CrossRef] 
6. Feng, L.; Wang, k.y.; Powell, J.; Zhou, H.C. Controllable Synthesis of Metal-Organic Frameworks and Their Hierarchical Assemblies. Matter 2019, 1, 801-824. [CrossRef]

7. Zhang, Q.; Tang, D.; Zhang, J.; Ni, R.; Xu, L.; He, T.; Lin, X.; Li, X.; Qiu, H.; Yin, S.; et al. Self-Healing Heterometallic Supramolecular Polymers Constructed by Hierarchical Assembly of Triply Orthogonal Interactions with Tunable Photophysical Properties. J. Am. Chem. Soc. 2019, 141, 17909-17917. [CrossRef]

8. Datta, S.; Saha, M.L.; Stang, P.J. Hierarchical Assemblies of Supramolecular Coordination Complexes. Acc. Chem. Res. 2018, 51, 2047-2063. [CrossRef]

9. Guo, X.Q.; Zhou, L.P.; Hu, S.J.; Cai, L.X.; Cheng, P.M.; Sun, Q.F. Hexameric Lanthanide-Organic Capsules with Tertiary Structure and Emergent Functions. J. Am. Chem. Soc. 2021, 143, 6202-6210. [CrossRef]

10. Li, G.L.; Zhou, Z.; Wang, B.; Cao, X.L.; Su, H.F.; Wang, W.; Huang, Y.G.; Hong, M.C. Constructing $\pi$-Stacked Supramolecular Cage Based Hierarchical Self-Assemblies via $\pi \cdots \pi$ Stacking and Hydrogen Bonding. J. Am. Chem. Soc. 2021, 143, 10920-10929. [CrossRef]

11. Sun, Z.W.; Li, P.; Xu, S.J.; Li, Z.Y.; Nomura, Y.; Li, Z.M.; Liu, X.Y.; Zhang, S.D. Controlled Hierarchical Self-Assembly of Catenated Cages. J. Am. Chem. Soc. 2020, 142, 10833-10840. [CrossRef]

12. Schoedel, A.; Li, M.; Li, D.; O'Keeffe, M.; Yaghi, O.M. Structures of Metal-Organic Frameworks with Rod Secondary Building Units. Chem. Rev. 2016, 116, 12466-12535. [CrossRef] [PubMed]

13. Rizzuto, F.J.; von Krbek, L.K.S.; Nitschke, J.R. Strategies for binding multiple guests in metal-organic cages. Nat. Rev. Chem. 2019, 3, 204-222. [CrossRef]

14. Yan, X.; Wang, M.; Cook, T.R.; Zhang, M.; Saha, M.L.; Zhou, Z.; Li, X.; Huang, F.; Stang, P.J. Light-emitting superstructures with anion effect: Coordination-driven self-assembly of pure tetraphenylethylene metallacycles and metallacages. J. Am. Chem. Soc. 2016, 138, 4580-4588. [CrossRef] [PubMed]

15. Krishnaswamy, S.; Chand, D.K. cis-Protected palladium(II) based binuclear complexes as tectons in crystal engineering and the imperative role of the cis-protecting agent. CrystEngComm 2017, 19, 5157-5172. [CrossRef]

16. Dai, D.-H.; Li, Z.; Yang, J.; Wang, C.-Y.; Wu, J.-R.; Wang, Y.; Zhang, D.-M.; Yang, Y.-W. Supramolecular Assembly-Induced Emission Enhancement for Efficient Mercury (II) Detection and Removal. J. Am. Chem. Soc. 2019, 141, 4756-4763. [CrossRef] [PubMed]

17. Zhou, Y.P.; Yang, X.; Zhang, M.T.; Guo, J.; Parkin, S.; Li, T.; Yu, F.Q.; Long, S.H. Synthon Polymorphism and $\pi-\pi$ Stacking in N-Phenyl-2-hydroxynicotinanilides. Cryst. Growth Des. 2021, 21, 6155-6165.

18. Wang, D.; Guo, G.; Chen, R.; Gong, Y.; Sun, L.; Zhao, Y. Single-crystal structure of two-dimensional organic framework based on donor-acceptor interactions with charge-transfer effect. Sci. China Chem. 2021, 64, 1510-1514. [CrossRef]

19. Beldjoudi, Y.; Narayanan, A.; Roy, I.; Pearson, T.J.; Mustafa, C.; Nguyen, M.T.; Krzyaniak, M.D.; Alsubaie, F.M.; Wasielewski, M.R.; Stupp, S.I.; et al. Supramolecular Tessellations by a Rigid Naphthalene Diimide Triangle. J. Am. Chem. Soc. 2019, 141, 17783-17795. [CrossRef] [PubMed]

20. Qu, L.; Iguchi, H.; Takaishi, S.; Habib, F.; Leong, C.F.; D’Alessandro, D.M.; Yoshida, T.; Abe, H.; Nishibori, E.; Yamashita, M. Porous Molecular Conductor: Electrochemical Fabrication of Through-Space Conduction Pathways among Linear Coordination Polymers. J. Am. Chem. Soc. 2019, 141, 6802-6806. [CrossRef]

21. Wang, J.; Gu, X.; Zhang, P.; Huang, X.; Zheng, X.; Chen, M.; Feng, H.; Kwok, R.T.K.; Lam, J.W.Y.; Tang, B.Z. Ionization and Anion $-\pi^{+}$Interaction: A New Strategy for Structural Design of Aggregation-Induced Emission Luminogens. J. Am. Chem. Soc. 2017, 139, 16974-16979. [CrossRef]

22. Burattini, S.; Greenland, B.W.; Merino, D.H.; Weng, W.; Seppala, J.; Colquhoun, H.M.; Hayes, W.; Mackay, M.E.; Hamley, I.W.; Rowan, S.J. A Healable Supramolecular Polymer Blend Based on Aromatic $\pi-\pi$ Stacking and Hydrogen-Bonding Interactions. J. Am. Chem. Soc. 2010, 132, 12051-12058. [CrossRef] [PubMed]

23. Bernstein, J.; Davis, R.E.; Shimoni, L.; Chang, N.L. Patterns in Hydrogen Bonding: Functionality and Graph Set Analysis in Crystals. Angew. Chem. Int. Ed. 1995, 34, 1555-1573. [CrossRef]

24. Wang, B.; Lin, R.B.; Zhang, Z.J.; Xiang, S.C.; Chen, B.L. Hydrogen-Bonded Organic Frameworks as a Tunable Platform for Functional Materials. J. Am. Chem. Soc. 2020, 142, 14399-14416. [CrossRef] [PubMed]

25. Li, J.T.; Kan, L.; Li, J.Y.; Liu, Y.L.; Eddaoudi, M. Quest for Zeolite-like Supramolecular Assemblies: Self-Assembly of Metal Organic Squares via Directed Hydrogen Bonding. Angew. Chem. Int. Ed. 2020, 59, 19659-19662. [CrossRef] [PubMed]

26. Yan, X.Z.; Wang, H.Z.; Hauke, C.E.; Cook, T.R.; Wang, M.; Saha, M.L.; Zhou, Z.X.; Zhang, M.M.; Li, X.P.; Huang, F.; et al. A Suite of Tetraphenylethylene-Based Discrete Organoplatinum(II) Metallacycles: Controllable Structure and Stoichiometry, Aggregation-Induced Emission, and Nitroaromatics Sensing. J. Am. Chem. Soc. 2015, 137, 15276-15286. [CrossRef]

27. Dong, J.Q.; Pan, Y.T.; Wang, H.; Yang, K.W.; Liu, L.M.; Qiao, Z.W.; Yuan, Y.D.; Peh, S.B.; Zhang, J.; Shi, L.L.; et al. Self-Assembly of Highly Stable Zirconium(IV) Coordination Cages with Aggregation Induced Emission Molecular Rotors for Live-Cell Imaging. Angew. Chem. Int. Ed. 2020, 59, 10151-10159. [CrossRef]

28. Zhang, Z.; Zhao, Z.; Wu, L.; Lu, S.; Ling, S.; Li, G.; Xu, L.; Ma, L.; Hou, Y.; Wang, X.; et al. Emissive Platinum(II) Cages with Reverse Fluorescence Resonance Energy Transfer for Multiple Sensing. J. Am. Chem. Soc. 2020, 142, 2592-2600. [CrossRef]

29. Zhao, J.; Zhou, Z.; Li, G.; Stang, P.J.; Yan, X. Light-Emitting Self-Assembled Metallacages. Nat. Sci. Rev. 2021, 8, nwab045. [CrossRef] 
30. Bhowal, R.; Chopra, D. Investigating the Role of Weak Interactions to Explore the Polymorphic Diversity in Difluorinated Isomeric N-Phenylcinnamamides. Cryst. Growth Des. 2021, 21, 4162-4177. [CrossRef]

31. Deng, W.; Yu, Z.S.; Ma, H.W.; Yu, S.Y. Self-Assembly of Water-Soluble Platinum(II)-Based Metallacalixarenes and Tuning Their Conformational Interconversion via Synergistic Effects between Solvents and Anions. Chem. Asian J. 2018, 13, $2805-2811$. [CrossRef]

32. Ma, T.T.; Tong, J.; Sun, W.Q.; Ma, H.W.; Yu, S.Y. Self-assembly of a Pd-based molecular bowl as anion receptor featured by multiple C-H $\cdots$ anion hydrogen bonds. Inorg. Chem. Commun. 2018, 91, 24-28. [CrossRef]

33. Yao, L.Y.; Qin, L.; Xie, T.Z.; Li, Y.Z.; Yu, S.Y. Synthesis and anion sensing of water-soluble metallomacrocycles. Inorg. Chem. 2011, 50, 6055-6062. [CrossRef] [PubMed]

34. Yu, S.Y.; Huang, H.; Liu, H.B.; Chen, Z.N.; Zhang, R.; Fujita, M. Modular Cavity-Tunable Self-Assembly of Molecular Bowls and Crowns as Structural Analogues of Calix[3]arenes. Angew. Chem. Int. Ed. 2003, 42, 686-690. [CrossRef] [PubMed]

35. Yu, S.-Y.; Kusukawa, T.; Biradha, K.; Fujita, M. Hydrophobic Assembling of a Coordination Nanobowl into a Dimeric Capsule Which Can Accommodate up to Six Large Organic Molecules. J. Am. Chem. Soc. 2000, 122, 2665-2666. [CrossRef]

36. Fujita, M.; Yu, S.Y.; Kusukawa, T.; Funaki, H.; Ogura, K.; Yamaguchi, K. Self-Assembly of Nanometer-Sized Macrotricyclic Complexes from Ten Small Component Molecules. Angew. Chem. Int. Ed. 1998, 37, 2082-2085. [CrossRef]

37. Liu, L.X.; Huang, H.P.; Li, X.; Sun, Q.F.; Sun, C.R.; Li, Y.Z.; Yu, S.Y. Coordination molecular hats binding acetonitrile via C-H ... $\pi$ interactions. Dalton Trans. 2008, 12, 1544-1546. [CrossRef]

38. Mu, Y.J.; Yu, L.N.; Jiang, X.F.; Yu, S.Y.; Yamaguchi, K. Self-assembly of an organo-palladium molecular basket that encapsulates cobalticarborane anion in water. Inorg. Chem. Commun. 2014, 44, 119-123. [CrossRef]

39. Yu, L.N.; Jiang, X.F.; Yu, S.Y. Self-Assembly of Chiral Nano-bowl from Chiral Pd-complex Building Corners and 4,7-Phenanthroline Linkers. Chin. J. Chem. 2015, 33, 152-155. [CrossRef]

40. Xie, T.Z.; Guo, C.; Yu, S.Y.; Pan, Y.J. Fine-Tuning Conformational Motion of a Self-Assembled Metal-Organic Macrocycleby Multiple CH...Anion Hydrogen Bonds. Angew. Chem. Int. Ed. 2012, 51, 1177-1181. [CrossRef]

41. Ning, G.H.; Xie, T.Z.; Pan, Y.J.; Li, Y.Z.; Yu, S.Y. Self-assembly of bowl-like trinuclearmetallo-macrocycles. Dalton Trans. 2010, 39 , 3203-3211. [CrossRef]

42. Zangrando, E.; Casanova, M.; Alessio, E. Trinuclear Metallacycles: Metallatriangles and Much More. Chem. Rev. 2008, 108, 4979-5013. [CrossRef]

43. Hess, J.L.; Hsieh, C.H.; Brothers, S.M.; Hall, M.B.; Darensbourg, M.Y. Self-Assembly of Dinitrosyl Iron Units into ImidazolateEdge-Bridged Molecular Squares: Characterization Including Mossbauer Spectroscopy. J. Am. Chem. Soc. 2011, 133, 20426-20434. [CrossRef]

44. Díaz-Ramírez, M.L.; Huggins, H.; Donnadieu, B.; Lopez, N.; Muñoz-Hernández, M.A. The quest for large Group 13 metallacalixarenes based onbenzymidazolyl ligands and Al and Ga alkyls. Eur. J. Inorg. Chem. 2021, 2021, 3896-3902. [CrossRef]

45. Steffen, A.; Braun, T.; Neumann, B.; Stammler, H.G. Palladium Fluoro Complexes: Useful Tools to Access Organometallic Metallamacrocycles. Angew. Chem. Int. Ed. 2007, 46, 8674-8678. [CrossRef]

46. Naranthatta, M.C.; Ramkumar, V.; Chand, D.K. Self-assembly of self-assembled molecular triangles. J. Chem. Sci. 2014, 126, 1493-1499. [CrossRef]

47. Naranthatta, M.C.; Ramkumar, V.; Chand, D.K. Role of peripheral phenanthroline groups in the self-assembly of self-assembled molecular triangles. J. Chem. Sci. 2015, 127, 273-280. [CrossRef]

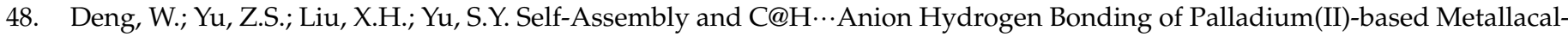
ixarenes Using Pyridyl- or Phenyl-Bridged Di-Naphthoimidazoles. Chem. Asian J. 2018, 13, 3173-3179. [CrossRef] [PubMed]

49. Du, W.T.; Tong, J.; Deng, W.; Wang, M.X.; Yu, S.Y. Coordination-driven self-assembly of palladium(II)-based metallacalixarenes as anion receptors using flexible pyridine-bridged diimidazole ligands. Chin. Chem. Lett. 2021, 32, 485-488.

50. Neilson, B.M.; Lynch, V.M.; Bielawski, C.W. Photoswitchable N-Heterocyclic Carbenes: Using Light to Modulate ElectronDonating Properties. Angew. Chem. Int. Ed. 2011, 50, 10322-10326. [CrossRef]

51. Gong, D.P.; Chen, J.F.; Zhao, Y.; Cao, D.K. Bisthienylethene $\mathrm{Th}_{2} \mathrm{im}$ and its complex $\left(\mathrm{Th}_{2} \mathrm{imH}\right)_{2}\left[\operatorname{ReCl} l_{6}\right]$ : Crystalline-phase photochromism, and photochemical regulation of luminescence and magnetic properties. Dalton Trans. 2016, 45, 3443-3449. [CrossRef]

52. Sheldrick, G.M. SHELXS-97; University of Göttingen: Göttingen, Germany, 1990

53. Sheldrick, G.M. SHELXL-97; University of Göttingen: Göttingen, Germany, 1997.

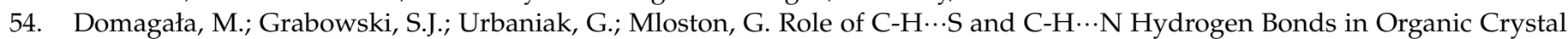
Structuress The Crystal and Molecular Structure of 3-Methyl-2,4-diphenyl-(1,3)-thiazolidine-5-spiro-2'-adamantane and 3-Methyl2,4,5,5-tetraphenyl-(1,3)-thiazolidine. J. Phys. Chem. A. 2003, 107, 2730-2736. [CrossRef]

55. Janiak, C. A critical account on $\pi-\pi$ stacking in metal complexes with aromaticnitrogen-containing ligands. J. Chem. Soc. Dalton Trans. 2000, 21, 3885-3896. [CrossRef]

56. Naranthatta, M.C.; Das, D.; Tripathy, D. Consequence of Presence and Absence of $\pi-$ Clouds at Strategic Locations of Designed Binuclear Pd(II) Complexes on Packing: Self Assembly of Self-Assembly by Intermolecular Locking and Packing. Cryst. Growth Des. 2012, 12, 6012-6022. [CrossRef]

57. Ramkumar, V.; Chand, D.K. Toppled Molecular-Domino Sets by Self-Assembly of Self-assembly: The $\pi$-Polymers Debakanta Tripathy. Cryst. Growth Des. 2013, 13, 3763-3772. 